\title{
Pengaruh Akuntabilitas dan Transparansi Lembaga Zakat Terhadap Tingkat Kepercayaan Muzakki Dalam Membayar Zakat Di Baitul Mal Kota Banda Aceh
}

\author{
Cut Delsie Hasrina ${ }^{* 1}$, Yusri ${ }^{1}$, Dwi Rianda Agusti $\mathrm{Sy}^{1}$ \\ ${ }^{1}$ Program Studi Akuntansi Fakultas Ekonomi Universitas Abulyatama, Aceh Besar, 23372, \\ Indonesia. \\ *Email korespondensi: cuthasrina@yahoo.com ${ }^{1}$
}

Diterima 14 Maret 2018; Disetujui 12 April 2018; Dipublikasi 30 April 2018

\begin{abstract}
To increase the potential of zakat at Baitul Mal Kota Banda Aceh then transparency should be prioritized in all aspects. This is important because if it increases then the level of trust muzakki also increased so that will create the desire to pay zakat. This research using purposive sampling method. The data used in the form of primary data by using questionnaires to 50 respondents from 492 muzakki at Baitul Mal Kota Banda Aceh. The methot of data processing is multiple regression SPSS 20.00 for windows program. The results of this study indicate that the variable accountability (X1) has a significant effect on the level of trust muzakki (Y), which is equal to 0.011 . The result can be proved by ttest $>$ ttable (2.732> 1.694). The variable transparency of zakatt institutions (X2) has no significant effect on the level of trust muzakki $(Y)$, which is equal to 0.113 . This can be proved by ttest <ttabel $(1.633<1.694)$ with significant $<0.05$. Furthermore, simultaneously the variable of accountability (X1) and zakat institution transparency (X2) have an effect on muzakki level trustl (Y), it is because Ftest> Ftable (16.414> 3.46).
\end{abstract}

Keywords: accountability, zakat institution transparency, muzakki trust level

Abstrak: Untuk peningkatan potensi zakat Baitul Mal Kota Banda Aceh maka tranparansi harus diutamakan dalam segala aspek. Hal ini penting karena apabila hal tersebut meningkatkan maka tingkat kepercayaan muzakki juga meningkat sehingga akan menciptakan keinginan membayar zakat..Penelitian ini menggunakan metode purposive sampling. Data yang digunakan berupa data primer dengan menggunakan kuesioner kepada 100 responden dari 492 populasi muzakki Baitul Mal Kota Banda Aceh. Pengolahan data dilakukan dengan bantuan model persamaan regresi berganda program SPSS 20,00 for windows. Hasil penelitian ini menunjukkan bahwa variabel akuntabilitas (X1) berpengaruh signifikan terhadap tingkat kepercayaan muzakki (Y), yaitu sebesar 0.011. Hasil tersebut dapat dibuktikan dengan nilai thitung $>$ ttabel $(2.732>1.694)$. Adapun variabel transparansi lembaga zakat (X2) berpengaruh tidak signifikan terhadap tingkat kepercayaan muzakki (Y), yaitu sebesar 0.113. Hal tersebut dapat dibuktikan dengan thitung $<$ tabel $(1.633<1.694)$ dengan signifikan $<0.05$. Selanjutnya secara simultan variabel akuntabilitas (X1) dan transparansi lembaga zakat (X2) berpengaruh terhadap tingkat kepercayaan muzakki (Y), hal tersebut dikarenakan $\mathrm{F}_{\text {hitung }}>\mathrm{F}_{\text {tabel }}(16.414>$ 3.46).

Kata kunci : akuntabilitas, transparansi lembaga zakat, tingkat kepercayaan muzakki 
Pengelolaan Zakat di Indonesia telah diatur dalam UU No 38/1999 tentang pengelolaan zakat yang mengatur semua kegiatan yang berhubungan dengan perencanaan, pengorganisasian, pelaksanaan, dan pengawasan terhadap pengumpulan dan pendistribusian serta pendayagunaan terhadap dana zakat. Dalam pasal 5 Undang-Undang Republik Indonesia No 38 Tahun 1999 tertera bahwa pengelolaan zakat bertujuan untuk meningkatkan pelayanan bagi masyarakat dalam menunaikan zakat sesuai dengan tuntunan agama, meningkatkan fungsi dan peranan pranata keagamaan dalam upaya mewujudkan kesejahteraan masyarakat dan keadilan sosial, serta meningkatkan hasil guna dan daya guna zakat.

Organisasi pengelola zakat di Indonesia terdiri atas Lembaga Amil Zakat (LAZ ) dan Badan Amil Zakat (BAZ) .Lembaga Amil Zakat (LAZ) di bentuk oleh pemerintah dibawah naungan Kementrian Agama dan tersebar hampir disetiap Provinsi, Kabupaten, Kota hingga kecamatan.Lembaga Amil zakat adalah lembaga yang dibentuk masyarakat yang bertugas untuk mengumpulkan, mendistribusikan dan mendayagunakan zakat (UU.No 23 Tahun 2011).

UIN Ar-Raniry bekerja sama dengan Baitul Mal Aceh (2014) melakukan penelitian tentang zakat di Aceh, hasil dari penelitian tersebut menggambarkan potensi zakat di provinsi Aceh mencapai Rp. 1.398.583.430.348,- per tahunnya. Pada tahun 2015, Baitul Mal Aceh dan Banda Aceh hanya mengumpulkan zakat sebesar Rp. 218.000.000.000,. Pada tahun 2016, potensi zakat di Aceh mencapai 1.400.000.000.000,-. Namun baru terealisasi sebesar Rp. 218.000.000.000,- dari potensi tersebut, yang terealisasi baru sepertiganya.
Realisasi itu merupakan zakat yang terkumpul oleh Baitul Mal Kota Banda Aceh. Jumlah penerimaan zakat pada Baitul Mal Kota Banda Aceh mulai tahun 2012-2016 adalah sebagai berikut.

Tabel 1 Jumlah penerimaan zakat di Kota Banda Aceh

\begin{tabular}{|c|c|c|c|c|}
\hline No & Tahun & Target (Rp.) & $\begin{array}{c}\text { Realisasi Zakat } \\
\text { (Rp.) }\end{array}$ & $\%$ \\
\hline 1 & 2012 & $8.000 .000 .000,-$ & 7.639.152.153,- & 8,31 \\
\hline 2 & 2013 & 14.237.722.547,- & 12.129.553.464,- & 55,38 \\
\hline 3 & 2014 & 15.736.222.547,- & 12.650.123.139,-- & 1,51 \\
\hline 4 & 2015 & 17.368.836.141,- & 13.789.549.463,-- & 7,18 \\
\hline 5 & 2016 & 18.504.500.000,- & 17.936.139.683,-- & 28,17 \\
\hline \multicolumn{3}{|c|}{ Jumlah } & 56.505.365.700,- & 100 \\
\hline
\end{tabular}

Sumber : Baitul Mal Kota Banda Aceh (2017)

Berdasarkan data pada tabel 1 diatas, jumlah target dan penerimaan zakat dari tahun 2012-2016 mengalami peningkatan. Baitul Mal Kota Banda Aceh sebagai lembaga zakat sudah mampu meningkatkan kepercayaan muzakki dalam menyalurkan zakat. Tabel berikut merupakan alokasi dana Baitul Mal Kota Banda Aceh :

Tabel 2 Alokasi dana Baitul Mal Kota Banda Aceh

\begin{tabular}{|c|c|c|}
\hline No & Uraian & Jumlah (Rp.) \\
\hline 1 & $\begin{array}{l}\text { Bantuan biaya pendidikan } \\
\text { tahfidz Al-Quran }\end{array}$ & 444.300.000,- \\
\hline 2 & $\begin{array}{l}\text { Bantuan } \mathrm{TPA} / \mathrm{TPQ} / \mathrm{TKA} \\
\text { sebanyak } 164 \text { tempat }\end{array}$ & $412.500 .000,-$ \\
\hline 3 & $\begin{array}{l}\text { Bantuan Balai Pengajian } \\
\text { sebanyak } 287 \text { tempat }\end{array}$ & $430.500 .000,-$ \\
\hline 4 & $\begin{array}{lll}\text { Bantuan } & \text { Majelis } & \text { Ta'lim } \\
\text { sebanyak } 195 \text { pengajian } & \end{array}$ & 487.500.000,- \\
\hline 5 & $\begin{array}{l}\text { Bantuan tajhis mayat laki-laki } \\
\text { dan perempuan sebanyak } 90 \\
\text { desa }\end{array}$ & $450.000 .000,-$ \\
\hline 6 & $\begin{array}{l}\text { Bantuan operasional masjid } \\
\text { sebanyak } 95 \text { mesjid }\end{array}$ & 380.000.000,- \\
\hline 7 & $\begin{array}{l}\text { Bantuan operasional mushalla } \\
\text { sebanyak } 130\end{array}$ & $390.000 .000,-$ \\
\hline & Jumlah & $2.994 .800 .000,-$ \\
\hline
\end{tabular}

Sumber : Baitul Mal Kota Banda Aceh (2017)

Faktor yang mempengaruhi keinginan membayar zakat yaitu akuntabilitas. Akuntabiltas harus diutamakan dalam mengelola karena dapat 
meningkatkan kepercayaan muzakki untuk keinginan membayar zakat pada Baitul Mal. Faktor lain yang mempengaruhi keinginan muzakki membayar zakat di Baitul Mal adalah transparansi. Salah satu sebeb transfaransi menjadi faktor yang penting dalam pengelolaam zakat adalah dengan adanya tranparansi maka muzakki mengetahui realisasi pengelolaan zakat yang mereka setor ke Baitul Mal.

Pengaruh akuntabilitas terhadap tingkat kepercayaan muzakki dapat dilihat dari bagaimana seorang muzakki akan berkesinambungan dalam membayar zakatnya langsung kepada mustahiq. Berdasarkan penelitian yang dilakukan oleh Tasnian (2008) ditentukan bahwa akuntabilitas administrasi zakat memiliki pengaruh terhadap tingkat kepercayaan muzakki dalam keinginan membayar zakat pada lembaga zakat.

Faktor yang mempengaruhi tingkat kepercayaan muzakki selanjutnya adalah transparansi. Pentingnya transparansi dalam menyelenggarakan dana zakat sangat mempengaruhi tingkat kepercayaan muzakki terhadap lembaga zakat. Transparansi juga telah menjadi tuntutan masyarakat sehingga merupakan kepedulian masyarakat terhadap lembaga yang mengelola dana umat. Berkaitan dengan ini, adapun hasil penelitian yang dilakukan oleh Hoirot (2013) menunjukkan bahwa transparansi pengelolaan dan zakat berpengaruh terhadap tingkat kepercayaan muzakki.

Hermawan (2010) melakukan penelitian tentang Akuntansi zakat dan upaya peningkatan transparansi dan akuntabilitas lembaga amil zakat menjelaskan bahwa ada pengaruh positif variabel akuntansi zakat terhadap variabel transparansi dan akuntabilitas lembaga amil zakat.
Berdasarkan uraian latar belakang masalah, maka tujuan penelitian ini adalah untuk mengetahui pengaruh akuntabilitas dan transparansi lembaga zakat baik secara simultan maupun parsial terhadap tingkat kepercayaan muzakki dalam membayar zakat di Baitul Mal Kota Banda Aceh

\section{METODOLOGI PENELITIAN}

\section{Populasi dan Sampel}

Populasi adalah wilayah generalisasi yang terdiri atas objek atau subjek yang mempunyai kualitas dan karakteristik tertentu yang ditetapkan oleh peneliti untuk dipelajari dan kemudian ditarik kesimpulannya (Sugiyono, 2009:72).Populasi dalam penelitian ini adalah muzakki pribadi yang berjumlah 492

Sampel adalah bagian dari populasi yaitu suatu prosedur dimana hanya sebagian dari populasi saja yang diambil dan dipergunakan untuk menentukan sifat serta ciri yang dikehendaki dari populasi (Nazir, 2005:271).Metode pengambilan sampel dalam penelitian ini adalah purposive sampling, yaitu teknik pengambilan sampel yang digunakan peneliti jika peneliti mempunyai pertimbanganpertimbangan tertentu dalam pengambilan sampel atau penentuan sampel untuk tujuan tertentu.Dalam hal ini, yang menjadi sampel adalah muzakki pribadi pada Baitul Mal Kota Banda Aceh, yang berjumlah 50 orang..

\section{Teknik Pengumpulan Data}

Teknik pengumpulan data yang digunakan dalam penelitian ini adalah : 
1. Penelitian Kepustakaan adalah salah satu cara untuk memperoleh data dengan membaca literatur-literatur dan buku yang berkaitan dengan permasalahan yang diteliti.

2. Penelitian Lapangan, yaitu yang dilakukan dengan cara mengedarkan daftar pertanyaan (kuisioner) kepada responden, yaitu muzakki Baitul Mal Kota Banda Aceh.

\section{Definisi Operasional Variabel}

Variabel penelitian yang digunakan dalam penelitian ini terdiri dari variabel independen, yaitu akuntabilitas $\left(\mathrm{X}_{1}\right)$ dan transparansi lembaga zakat $\left(\mathrm{X}_{2}\right)$ dan satu variabel dependen yaitu tingkat kepercayaan muzakki (Y). Operasional Variabel yang digunakan dalam penelitian ini adalah :

Tabel 3 Operasional Variabel dan Pengukuran

\begin{tabular}{|c|c|c|c|c|}
\hline No & Variabel & Definisi & Indikator & Skala \\
\hline 1 & $\begin{array}{l}\text { akuntabi } \\
\text { litas } \\
\left(\mathrm{X}_{1}\right)\end{array}$ & $\begin{array}{l}\text { Kemampua } \\
\mathrm{n} \text { memberi } \\
\text { jawaban } \\
\text { kepada } \\
\text { otoritas } \\
\text { yang lebih } \\
\text { tinggi atas } \\
\text { tindakan } \\
\text { seseorang/s } \\
\text { ekelompok } \\
\text { orang } \\
\text { terhadap } \\
\text { masyarakat } \\
\text { luas dalam } \\
\text { suatu } \\
\text { organisasi }\end{array}$ & $\begin{array}{l}\text { 1. Semua } \\
\text { organ } \\
\text { perusahaan } \\
\text { dan semua } \\
\text { karyawan } \\
\text { mempunyai } \\
\text { kemampuan } \\
\text { sesuai } \\
\text { dengan } \\
\text { tugas, } \\
\text { tanggungja } \\
\text { wab dan } \\
\text { perannya } \\
\text { 2. Adanya } \\
\text { sistem } \\
\text { pengendali } \\
\text { internal } \\
\text { yang efektif } \\
\text { dalam } \\
\text { pengelolaan } \\
\text { perusahaan } \\
\text { 3. Adanya } \\
\text { ukuran } \\
\text { kinerja } \\
\text { untuk } \\
\text { semua } \\
\text { jajaran } \\
\text { perusahaan } \\
\text { yang } \\
\text { konsisten } \\
\text { dengan } \\
\text { nilai-nilai } \\
\text { perusahaan, } \\
\text { sasaran }\end{array}$ & Ordinal \\
\hline
\end{tabular}

\begin{tabular}{|c|c|c|c|c|}
\hline No & Variabel & Definisi & Indikator & Skala \\
\hline & & & $\begin{array}{l}\text { utama dan } \\
\text { strategi } \\
\text { perusahaan, } \\
\text { serta } \\
\text { memiliki } \\
\text { sistem } \\
\text { penghargaa } \\
\text { n dan } \\
\text { sanksi } \\
\text { 4. Setiap } \\
\text { organ } \\
\text { perusahaan } \\
\text { dan semua } \\
\text { karyawan } \\
\text { harus } \\
\text { berpegang } \\
\text { pada etika } \\
\text { bisnis dan } \\
\text { pedoman } \\
\text { perilaku } \\
\text { yang telah } \\
\text { disepakati }\end{array}$ & \\
\hline 2 & $\begin{array}{l}\text { Transpa } \\
\text { ransi } \\
\text { lembaga } \\
\text { zakat } \\
\left(\mathrm{X}_{2}\right)\end{array}$ & $\begin{array}{l}\text { Memberika } \\
\mathrm{n} \text { informasi } \\
\text { keuangan } \\
\text { yang } \\
\text { terbuka dan } \\
\text { jujur } \\
\text { kepada } \\
\text { masyarakat, } \\
\text { berdasarkan } \\
\text { pertimbang } \\
\text { an bahwa } \\
\text { masyarakat } \\
\text { memiliki } \\
\text { hak untuk } \\
\text { mengetahui } \\
\text { secara } \\
\text { terbuka dan } \\
\text { menyeluruh } \\
\text { pertanggun } \\
\text { gjawaban } \\
\text { dalam } \\
\text { pengelolaan } \\
\text { sumber } \\
\text { daya yang } \\
\text { dipercayaka } \\
\text { n kepadanya } \\
\text { dan } \\
\text { ketaatannya } \\
\text { kepada } \\
\text { peraturan } \\
\text { perundang- } \\
\text { undangan }\end{array}$ & $\begin{array}{l}\text { 1. Adanya } \\
\text { pemberian } \\
\text { informasi } \\
\text { keuangan } \\
\text { yang tepat } \\
\text { waktu, } \\
\text { memadai, } \\
\text { jelas, } \\
\text { akurat, } \\
\text { dapat } \\
\text { diperbandin } \\
\text { gkan, } \\
\text { mudah } \\
\text { diakses } \\
\text { publik } \\
\text { 2. Adanya } \\
\text { pengungka } \\
\text { pan kondisi } \\
\text { keuangan } \\
\text { secara } \\
\text { menyeluruh } \\
\text { 3. Adanya } \\
\text { keterbukaa } \\
\text { n tidak } \\
\text { mengurangi } \\
\text { kerahasiaan } \\
\text { perusahaan } \\
\text { 4. Adanya } \\
\text { kebijakan } \\
\text { perusahaan } \\
\text { yang } \\
\text { tertulis dan } \\
\text { secara } \\
\text { proporsiona } \\
\text { 1 } \\
\text { dikomunika } \\
\text { sikan } \\
\text { kepada } \\
\text { stakeholder } \\
\text { s. }\end{array}$ & Ordinal \\
\hline
\end{tabular}




\begin{tabular}{|c|c|c|c|c|}
\hline No & Variabel & Definisi & Indikator & Skala \\
\hline 3 & $\begin{array}{l}\text { Tingkat } \\
\text { keperca } \\
\text { yaan } \\
\text { muzakki } \\
\text { (Y) }\end{array}$ & $\begin{array}{l}\text { Kemauan } \\
\text { muzakki } \\
\text { untuk } \\
\text { mengandalk } \\
\text { an lembaga } \\
\text { zakat atau } \\
\text { Baitul Mal } \\
\text { untuk } \\
\text { menyalurka } \\
\text { n zakatnya } \\
\text { kepada } \\
\text { mustahiq } \\
\text { karena } \\
\text { muzakki } \\
\text { yakin } \\
\text { lembaga } \\
\text { tersebut } \\
\text { profesional, } \\
\text { amanah dan } \\
\text { transparan }\end{array}$ & $\begin{array}{l}\text { 1. Credibility } \\
\text { (dapat } \\
\text { dipercaya } \\
\text { 2. Competenc } \\
y \\
\text { (kemampua } \\
\mathrm{n} \\
\text { 3. Courtesy } \\
\text { (sikap } \\
\text { moral) }\end{array}$ & Ordinal \\
\hline
\end{tabular}

\section{Pengujian Validitas dan Reliabilitas}

\section{Uji Validitas}

Uji validitas adalah untuk mengetahui tingkat kevalidan dari instrumen kuesioner yang digunakan dalam pengumpulan data. Uji validitas ini dilakukan untuk mengetahui apakah item-item yang tersaji dalam kuesioner benar-benar mampu mengungkapkan dengan pasti apa yang akan diteliti.

Adapun kriteria pengambilan keputusan uji validitas instrument dalam penelitian ini adalah dengan membandingkan nilai $r_{\text {hitung }}$ pada setiap butir pernyataan dengan nilai $r_{\text {tabel. }}$ Jika nilair $r_{\text {hitung }}>r_{\text {tabel, }}$ maka butir pernyataannya pada setiap variabel tersebut dinyatakan valid dan sebaliknya jika nilair $_{\text {hitung }}<\mathrm{r}_{\text {tabel, }}$ maka butir pernyataannya pada setiap variabel tersebut tidak valid.

\section{Uji Reliabilitas}

Uji reliabilitas dilakukan untuk mengetahui sejauh mana hasil pengukuran relatif konsisten apabila dilakukan pengujian ulang.Uji ini dilakukan apabila pernyataan-pernyataan sudah valid. Pengujian reliabilitas juga dilakukan secara statistik, yaitu dengan menghitung besarnya nilai cronbach's alpha dengan bantuan program SPSS. Instrument dalam penelitian ini dikatakan reliabel apabila nilai alphanya lebih besar dari 0,5

\section{Analisis Regresi Linier Berganda}

Adapun metode analisis data digunakan untuk menjawab hipotesis penelitian yaitu, untuk mengetahui pengaruh atau tidaknya akuntabilitas dan transparansi lembaga zakat terhadap tingkat kepercayaan muzakki adalah dengan analisis regresi linier berganda dengan bantuan program SPSS versi 20. Dengan persamaan sebagai berikut :

$$
\mathbf{Y}=\alpha+\beta_{1} \mathbf{X}_{1}+\beta_{2} \mathbf{X}_{2}+\varepsilon
$$

$$
\begin{aligned}
& \text { Keterangan : } \\
& \mathrm{Y}=\text { tingkat kepercayaan muzakki } \\
& \alpha=\text { konstanta } \\
& \mathrm{X}_{1}=\text { akuntabilitas } \\
& \mathrm{X}_{2}=\text { transparansi lembaga zakat } \\
& \beta_{1} \beta_{2}=\text { Koefisien } \mathrm{X}_{1} \mathrm{X}_{2} \\
& \varepsilon \quad=\text { Error term }
\end{aligned}
$$

\section{Uji Simultan (Uji-F)}

Uji F merupakan pengujian terhadap koefisien regresi secara bersama-sama yaitu pengaruh dari seluruh variabel independen $(\mathrm{X})$ terhadap variabel dependen (Y). Adapun kriteria pengambilan keputusannya adalah : Jika $F_{\text {hitung }}>F_{\text {tabel, }}$ maka akuntabilitas dan transparansi lembaga zakat secara bersama-sama berpengaruh signifikan terhadap tingkat kepercayaan muzakki dalam membayar zakat di Baitul Mal Kota Banda Aceh. Jika $\mathrm{F}_{\text {hitung }}<\mathrm{F}_{\text {tabel, }}$ maka akuntabilitas dan transparansi secara bersama-sama tidak berpengaruh signifikan terhadap tingkat kepercayaan muzakki dalam membayar zakat di Baitul Mal Kota Banda Aceh. 


\section{Uji Parsial (Uji-t)}

Uji t digunakan untuk menguji hipotesis secara parsial guna menunjukkan pengaruh tiap variabel independen secara individu terhadap variabel dependen. Pengujian ini akan membandingkan hasil perhitungan $\mathrm{t}_{\text {hitung }}$ dengan $\mathrm{t}_{\text {tabel. }}$ Kesimpulan untuk uji- $\mathrm{t}$ adalah Jika $t_{\text {hitung }}>t_{\text {tabel, }}$ bermakna akuntabilitas dan transparansi lembaga zakat secara parsial berpengaruh signifikan terhadap tingkat kepercayaan muzakki dalam membayar zakat di Baitul Mal Kota Banda Aceh. Jika $t_{\text {hitung }}<t_{\text {tabel, }}$ maka akuntabilitas dan transparansi lemabag zakat secara parsial tidak berpengaruh signifikan terhadap tingkat kepercayaan muzakki dalam membayar zakat di Baitul Mal Kota Banda Aceh.

\section{HASIL DAN PEMBAHASAN}

\section{Deskriptif Responden}

Responden yang berjenis kelamin laki-laki sebanyak 39 orang dan yang berjenis kelamin perempuan 11 orang.Jadi, dapat disimpulkan bahwa responden yang berjenis kelamin laki-laki yang paling banyak dalam penelitian ini yaitu sebanyak 39 orang.

Tabel 4 Karakteristik Responden Berdasarkan Jenis Kelamin

Responden yang bekerja sebagai pedagang 20 orang, pengusaha 9 orang, wiraswasta 6 orang, asosiasi saudagar aceh 5 orang, karyawan 7 orang dan apoteker kimia 3 orang. Jadi responden yang

\begin{tabular}{ccc}
\hline No & Jenis Kelamin & $\begin{array}{r}\text { Jumlah } \\
\text { Responden }\end{array}$ \\
\hline 1 & Laki-laki & 39 \\
2 & Perempuan & 11 \\
\hline & Jumlah & $\mathbf{5 0}$
\end{tabular}

paling banyak dalam penelitian ini adalah pedagang yaitu sebanyak 20 orang.
Tabel 5 Karakteristik Responden Berdasarkan Pekerjaan

\begin{tabular}{ccc}
\hline No & Pekerjaan & Responden \\
\hline 1 & Pedagang & 20 \\
2 & Pengusaha & 9 \\
3 & Wiraswasta & 6 \\
4 & Asosiasi Saudagar Aceh & 5 \\
5 & Karyawan & 7 \\
6 & Apoteker & 3 \\
\hline & Jumlah & $\mathbf{5 0}$ \\
\hline
\end{tabular}

\section{Uji Validitas}

Uji validitas terhadap 50 orang responden dengan 12 pertanyaan yang menyangkut variabel akuntabilitas, variabel transparansilembaga zakat dan variabel tingkat kepercayaan muzakki. Nilai $r$ tabeldengan ketentuan $\mathrm{df}=12$ dan tingkat signifikan sebesar $5 \%$, angka yang diperoleh $=0,576$ yang hasilnya dapat dilihat pada tabel dibawah ini

\begin{tabular}{ccccc}
\multicolumn{6}{l}{ Tabel 6 Uji Validitas } \\
\hline No & Pertanyaan & $\mathbf{r}_{\text {hitung }}$ & $\mathbf{r}_{\text {table }}$ & Keterangan \\
& & & & \\
\hline 1 & $\mathrm{~A} 1$ & 0.716 & 0.576 & Valid \\
2 & $\mathrm{~A} 2$ & 0.751 & 0.576 & Valid \\
3 & $\mathrm{~A} 3$ & 0.833 & 0.576 & Valid \\
4 & $\mathrm{~A} 4$ & 0.716 & 0.576 & Valid \\
5 & $\mathrm{~B} 1$ & 0.597 & 0.576 & Valid \\
6 & $\mathrm{~B} 2$ & 0.796 & 0.576 & Valid \\
7 & $\mathrm{~B} 3$ & 0.660 & 0.576 & Valid \\
8 & $\mathrm{~B} 4$ & 0.620 & 0.576 & Valid \\
9 & $\mathrm{C} 1$ & 0.959 & 0.576 & Valid \\
10 & $\mathrm{C} 2$ & 0.773 & 0.576 & Valid \\
11 & $\mathrm{C} 3$ & 0.773 & 0.576 & Valid \\
12 & $\mathrm{C} 4$ & 0.581 & 0.576 & Valid \\
\hline S
\end{tabular}

Sumber : Hasil Penelitian (November, 2017) diolah.

\section{Uji Reabilitas}

Pada tabel 7 dapat dilihat bahwa nilai ralpha $>$ $\mathrm{r}_{\text {tabel }}(0.934>0.576)$, maka kuesioner yang terdiri dari 12 pertanyaan tersebut dinyatakan reliabel. 
Tabel 7 Uji Reliabilitas

\begin{tabular}{|c|c|}
\hline Ralpha & Jumlah pertanyaan \\
\hline 0.934 & 12 \\
\hline
\end{tabular}

Sumber : Hasil Penelitian (November, 2017) diolah.

\section{Analisis Linier Berganda}

Hasil analisis dengan menggunakan model regresi linier berganda yang telah memenuhi uji normalitas antara variabel bebas yang terdiri dari variabel akuntabilitas dan transparansilembaga zakat terhadap tingkat kepercayaan muzakki, dapat dilihat pada tabel dibawah ini :

Tabel 8 Analisis Linier Berganda

\begin{tabular}{|c|c|r|r|r|r|r|}
\hline \multirow{2}{*}{ Model } & \multicolumn{2}{|c|}{$\begin{array}{l}\text { Unstandardized } \\
\text { Coefficients }\end{array}$} & $\begin{array}{l}\text { Standardized } \\
\text { Coefficients }\end{array}$ & \multirow{2}{*}{$\mathrm{t}$} & \multirow{2}{*}{ Sig. } \\
\cline { 3 - 7 } & & $\begin{array}{c}\text { Std. } \\
\text { Error }\end{array}$ & \multicolumn{2}{|c|}{ Beta } & & \\
\hline \multirow{2}{*}{1} & Constant & 2.983 & 0.461 & & 6.476 & 0.000 \\
\cline { 2 - 7 } & $\mathrm{x} 1$ & 0.403 & 0.148 & 0.568 & 2.732 & 0.011 \\
\cline { 2 - 7 } & $\mathrm{x} 2$ & 0.245 & 0.150 & 0.340 & 1.633 & 0.113 \\
\hline
\end{tabular}

Sumber : Hasil Penelitian (November, 2017) diolah.

Berdasarkan hasil pengolahan data pada tabel di atas, diperoleh persamaan linier berganda sebagai berikut :

$$
\mathrm{Y}=2.983+0.403 \mathrm{X}_{1}+0.245 \mathrm{X}_{2}
$$

Berdasarkan persamaan tersebut di atas dapat disimpulkan bahwa :

1. Konstanta $=2.983$, artinya bahwa variabel akuntabilitas dan transparansi lembaga zakat terhadap tingkat kepercayaan muzakki mempunyai hubungan positif sebesar 2.983. Hal terssebut menggambarkan bahwa pabila variabel akuntabilitas $\left(\mathrm{X}_{1}\right)$ dan variabel transparansi lembaga zakat $\left(\mathrm{X}_{2}\right)$ sama dengan 0 , maka tingkat kepecayaan muzakki (Y) akan tetap sebesar 2.983.
2. Nilai koefisien $X_{1}=0.403$, artinya pengaruh akuntabilitas $\left(\mathrm{X}_{1}\right)$ terhadap tingkat kepercayaan muzakki (Y) memiliki hubungan positif sebesar 0.403. Dengan demikian jika kenaikan variabel akuntabilitas $\left(\mathrm{X}_{1}\right) 1 \%$, maka akan terjadi kenaikan sebesar 0.403 terhadap tingkat kepercayaan muzakki (Y).

3. Nilai koefisien $\mathrm{X}_{2}=0.245$, artinya pengaruh variabel transparansi lembaga zakat $\left(\mathrm{X}_{2}\right)$ terhadap tingkat kepercayaan muzakki (Y) memiliki hubungan positif sebesar 0.245 . Hal ini dapat diartikan jika kenaikan variabel transparansi lembaga zakat sebesar $1 \%$, maka akan terjadi kenaikan sebesar 0.245 terhadap tingkat kepercayaan muzakki (Y).

\section{Uji Signifikan (Uji-F)}

Uji F dilakukan untuk melihat secara bersamasama pengaruh positif dan signifikan variabel bebas yang terdiri dari variabel akuntabilitas dan transparansi lembaga zakat terhadap tingkat kepercayaan muzakki.

Dari hasil tabel 9 di atas dapat dinilai $\mathrm{F}_{\text {hitung }}$ sebesar 54.958, sedangkan $\mathrm{F}_{\text {tabel }}$ didapat nilai 3.46 sehingga $F_{\text {hitung }}>F_{\text {tabel }}(16.414>3.46)$ dan signifikan pada tingkat 0.000 , hasil tersebut membuktikan bahwa variabel bebas yang terdiri dari akuntabilitas $\left(\mathrm{X}_{1}\right)$ dan transparansi lembaga zakat $\left(\mathrm{X}_{2}\right)$ secara bersama-sama berpengaruh signifikan terhadap tingkat kepercayaan muzakki (Y). 


\section{Tabel 9 Hasil Uji F}

ANOVA $^{\mathrm{a}}$

\begin{tabular}{|c|l|r|r|r|r|r|}
\hline \multicolumn{2}{|c|}{ Model } & $\begin{array}{c}\text { Sum of } \\
\text { Squares }\end{array}$ & Df & $\begin{array}{c}\text { Mean } \\
\text { Square }\end{array}$ & F & Sig. \\
\hline \multirow{3}{*}{1} & Regression & 17.407 & 2 & 8.704 & 54.958 & $.000^{\mathrm{b}}$ \\
\cline { 2 - 7 } & Residual & 4.593 & 48 & .158 & & \\
\cline { 2 - 7 } & Total & 22.000 & 50 & & & \\
\hline
\end{tabular}

a. Dependent Variable: y

b. Predictors: (Constant), x2, x1

Hasil peneitian ini konsisten dengan hasil penelitian Rahmawati (2014) yang menyebutkan bahwa akuntabilitas dan transparansi secara simultan berpengaruh signifikan terhadap penerimaan zakat

\section{Uji Signifikan Parsial (Uji-t)}

Uji-t dilakukan untuk menguji secara parsial variabel bbas yang terdiri dari variabel akuntabilitas $\left(\mathrm{X}_{1}\right)$ dan transparansi lembaga zakat $\left(\mathrm{X}_{2}\right)$ dan variabel tingkat kepercayaan muzakki(Y).

Tabel 10 Hasil Uji-t

\begin{tabular}{|c|c|r|r|}
\hline \multicolumn{2}{|c|}{ Model } & T & Sig. \\
\hline \multirow{2}{*}{1} & (Constant) & 6.476 & .000 \\
\cline { 2 - 4 } & $\mathrm{x} 1$ & 2.732 & .011 \\
\cline { 2 - 4 } & $\mathrm{x} 2$ & 1.633 & .113 \\
\hline
\end{tabular}

Sumber : Hasil Penelitian (November, 2017) diolah.

Berdasarkan tabel diatas terlihat bahwa :

1. Nilai $t_{\text {hitung }}$ variabel akuntabilitas $\left(\mathrm{X}_{1}\right)$ sebesar 2.732 berpengaruh secara positif dan signifikan sebesar 0,011. hipotesis Ha diterima karena $t_{\text {hitung }}>t_{\text {tabel }}(2.732>1.694)$ dan signifikan 0.05 $(0.011<0.05)$, yang berarti bahwa variabel akuntabilitas $\left(\mathrm{X}_{1}\right)$ signifikan terhadap variabel (Y) berupa tingkat kepercayaan muzakki. Hasil penelitian ini konsisten dengan penelitian yang dilakukan oleh Syafiq (2016) yang menyimpulkan bahwa akuntabilitas sangat dibutuhkan dalam pengelolaan zakat
2. Nilai $t_{\text {hitung }}$ variabel transparansi lembaga zakat $\left(\mathrm{X}_{2}\right)$ sebesar 1.633 berpengaruh secara positif dan signifikan sebesar 0.113. Hipotesis $\mathrm{Ha}$ ditolak karena $t_{\text {hitung }}<t_{\text {tabel }}(1.633<1.694)$ dan signifikan $0.05(0.113>0.05)$ yang berarti bahwa variabel transparansi $\left(\mathrm{X}_{2}\right)$ tidak signifikan terhadap variabel (Y) berupa tingkat kepercayaan muzakki. Hasil penelitian ini konsisten dengan hasil penelitian Rahmawati (2014) yang mengatakan tidak ada hubungan yang linier antara transparansi dengan tingkat kepercayaan muzakki. Tetapi penelitian ini tidak sejalan dengan penelitian yang dilakukan oleh Nasim (2014) yang menjelaskan bahwa transparansi berpengaruh secara signifikan terhadap tingkat kepercayaam muzakki.

\section{KESIMPULAN DAN SARAN}

\section{Kesimpulan}

Berdasarkan hasil penelitian dan pembahasan yang telah dilakukan, dapat disimpulkan bahwa :

1. Berdasarkan hasil penelitian bahwa variabel akuntabilitas $\left(\mathrm{X}_{1}\right)$ dan transparansi lembaga zakat $\left(\mathrm{X}_{2}\right)$ secara bersama-sama berpengaruh signifikan terhadap tingkat kepercayaan muzakki (Y). Dimana melihat probabilitasnya (Sig) yang lebih kecil dari taraf signifikan (0.000) maka dapat disimpulkan bahwa bentuk persamaan tersebut diterima dan berpengaruh signifikan. 
2. Variabel akuntabilitas $\left(\mathrm{X}_{1}\right)$ berpengaruh signifikan terhadap tingkat kepercayaan muzakki (Y), yaitu sebesar 0.011. Hasil tersebut dapat dibuktikan dengan nilai $t_{\text {hitung }}>t_{t a b e l}(2.732>$ 1.694). Adapun variabel transparansi lembaga zakat $\left(\mathrm{X}_{2}\right)$ tidak berpengaruh signifikan terhadap tingkat kepercayaan muzakki (Y), yaitu sebesar 0.113. Hal tersebut dapat dibuktikan dengan $t_{\text {hitung }}<t_{\text {tabel }}(1.633<1.694)$ dengan signifikan $<$ 0.05 .

\section{Saran}

Berdasarkan hasil penelitian ini, saran atau masukan adalah sebagai berikut :

1. Kepada Baitul Mal Kota Banda Aceh, berdasarkan hasil pembahasan yang telah diuraikan variabel transparansi lembaga zakat tidak berpengaruh signifikan terhadap tingkat kepercayaan muzakki. Jadi harus lebih diperhatikan lagi variabel-variabel tersebut agar tingkat kepercayaan muzakki meningkat.

2. Bagi peneliti selanjutnya, dapat melanjutkan penelitian pada faktor-faktor lain seperti, intergritas, professional dan lain sebagainya.

\section{DAFTAR PUSTAKA}

Hermawan, S. (2010). Akuntansi zakat, upaya transparansi dan akuntabilitas lembaga amil zakat. Jurnal ekonomi Fakultas Ekonomi Universitas Muhammadiyah Sidoarjo . Hal 34-42.

Hoirot. (2013). Pengaruh transparansi pada lembaga amil zakat dompet duafa, ciputat. Jurnal.

Nasim dan Ramadhan. (2014). Pengaruh transparansi laporan keuangan, pengelolaan zakat dan sikap pengelola terhadap tingkat kepercayaam muzakki. Ejournal Upi.

Rahmawati. (2014). Pengaruh akuntabilitas dan transparansi terhadap penerimaan zakat pada badan amil zakat kota Palopo. Jurnal akuntansi Sekolah Tinggi Ilmu Ekonomi Muhammadyah Palopo.

Sugiyono. (2009). Metode Penelitian Bisnis. Bandung: Alfabeta.

Syafiq, Ahmad. (2016). Urgensi peningkatan akuntanbilitas lembaga pengelolaan Zakat. Jurnal Ziswaf Vol. 3 No, 1

Undang-Undang Republik Indonesia Nomor 38 Tahun 1999 tentang Pengelolan Zakat.

- How to cite this paper :

Hasrina, C. D., Yusri, Y., \& Agusti Sy, D. R. (2018). Pengaruh Akuntabilitas Dan Transparansi Lembaga Zakat Terhadap Tingkat Kepercayaan Muzakki Dalam Membayar Zakat Di Baitul Mal Kota Banda Aceh. Jurnal Humaniora, 2(1), 19. 